\title{
EFFICIENCY OF TWO BACTERIAL STRAINS, Bacillus subtilis BS2 AND B. mycoides BM7, ISOLATED FROM PETROLEUM - POLLUTED LANDS FOR BIOREMEDIATION OF HYDROCARBONS-POLLUTED SOIL IN SAUDI ARABIA Al-Tuwaijri, Majdah M. Y. \\ Botany Department, Faculty of Applied Science (Girls Branch), Umm Al Qura University, Makah Almokarramah, Saudi Arabia
}

\begin{abstract}
The efficiency of two bacterial strains, namely: Bacillus subtilis Bs2 and $B$. mycoides $\mathrm{Bm} 7$ that have been previously isolated from petroleum-polluted soil in Saudi Arabia, for bioremediation of hydrocarbons-polluted soil were studied. The results indicated that both bacterial strains played an influential role in elimination of the phytotoxicity of benzene and toluene as evidenced by the pronounced increments in percentages of grain germination and viability of emerged seedlings, chlorophylls and carotenoids pigments contents of leaves as well as the significant improvement in plant growth vigor (root length, plant height and biomass gain) of barley (Hordeum vulgare L.) "Madini" cultivar as compared to that cultivated in untreated hydrocarbonpolluted soil under the same environmental conditions. However, B. subtilis Bs2 proved by far to surpass $B$. mycoides $\mathrm{Bm} 7$ in its bioremediation potential.

Keywords: Petroleum, , benzene, toluene, bioremediation, grain germination, growth vigor, barley, Bacillus subtilis, B. mycoides.
\end{abstract}

\section{INTRODUCTION}

Petroleum pollution is a serious obstacle to photosynthesis that affects the fundamental life and productivity of the sea (Duke et al., 2000). Not all oil released from land sources is quickly washed away to sea: moreover, pipeline and oil-well accidents, unregulated industrial wastes, and leaking underground storage tanks can all permanently contaminate large areas of soil, making them economically useless as well as dangerous to the health of organisms living in and around them (El-Baz, 1992; Hashem, 1996). Biological treatment of petroleum contamination has long been accepted as a treatment technology by which petroleum and other hydrocarbons may be eliminated from the environment (Raymond et al., 1967; Atlas, 1981, 1995; Hashem, 2004).

The localization of hydrocarbon-assimilating microorganisms in oil contaminated environments has received a considerable attention by many investigators because of the possibility of utilizing their degradation potential in bioremediation of petroleum contaminated soil (Inoue and Horikoshi, 1989; Utkin et al., 1992; ljah and Ukpe, 1992; Rowland and Atlas, 1995; Venosa et al., 1996; Lehmann, 1998; Chaineau et al., 1999; Reardon et al., 2000; Lee and Lee, 2001; Rosenberg, 2006; Yakubu et al., 2007; Kim et al. , 2008; Saadoun and Alawawdeh, 2008; Wolicka et al., 2009; Yudono et al., 2009).

In Saudi Arabia, biodegradation of petroleum hydrocarbons as well as bioremediation and rehabilitation of petroleum-polluted soils by using microorganisms has been an area of interest for many years (Abu-Zinada 
and Sabek, 1980; Sallal, 1995; Hashem, 1995; 1996; 2004; Hashem and AlObaid, 1996).

In a previous communication two bacterial strains, namely: Bacillus subtilis Bs2 and B. mycoides $\mathrm{Bm} 7$, have been isolated from petroleumpolluted soil at the Eastern region in Saudi Arabia; both of which proved to be capable of degrading benzene and toluene in vitro (Al-Tuwaijri, 2009). The present study was conducted to investigate the feasibility of using these bacterial strains to remediate soil polluted with the aromatic hydrocarbons (benzene and toluene), and to elucidate the possible effects of the various treatment of soil on grain germination and growth vigor of barley plant (Hordeum vulgare L.).

\section{MATERIALS AND METHODS}

\section{Bacterial strains}

A vast number of bacterial strains have been previously isolated from petroleum-polluted soils at the Eastern region in Saudi Arabia. The isolates were screened for their capacity to utilize benzene and toluene as sole source of carbon and energy. Two isolates of Gram-positive endospore forming bacilli identified as Bacillus subtilis (strain No. Bs2) and B. mycoides (strain No. Bm7) exhibited the highest benzene and toluene degrading potentials (Al-Tuwaijri, 2009). The two prospective isolates were routinely cultured on nutrient agar slants and maintained as bacterial suspensions in $20 \%$ glycerol $(\mathrm{v} / \mathrm{v})$ at $-20^{\circ} \mathrm{C}$. Both isolates were employed in the present study.

\section{Soil treatment and culture conditions}

Aliquot of composite soil was distributed in cloth bags $(5 \mathrm{~kg}$, each) and sterilized at $121^{\circ} \mathrm{C}$ by autoclaving on three separate occasions for 1 hour each time, with a $24 \mathrm{~h}$ interval between each one. Thereafter, the contents of the bags were put in plastic pots $(30 \mathrm{~cm}$ diameter and $25 \mathrm{~cm}$ depth) that have been previously sterilized by dipping in $5 \%$ formaldehyde solution, and left for 4 days to be well aerated. The pots were then transferred to a glasshouse, and divided into 8 sets (5 pots each); one set was left untreated to serve as a control, another one set was inoculated with $B$. subtilis to serve as a positive control. Another 2 sets were amended with hydrocarbon; one set with benzene and the other one with toluene, to serve as negative controls.

Treatments were conducted as follow: two sets of pots were amended with benzene and inoculated with bacteria; one (5 pots) with $B$. subtilis and the other 5 pots with $B$. mycoides. The remaining 2 sets were amended with toluene and inoculated with bacteria, one with $B$. subtilis and the other with $B$. mycoides. Soil inoculation with the prospective bacterial strains (B. subtilis Bs2 and B. mycoides Bm7, was performed using $100 \mathrm{ml}$ of a dense bacterial suspension (approximately 1.4-1.5 x 10 $\mathrm{CFU} / \mathrm{ml}$ ) of $48 \mathrm{~h}$-old culture per pot. The pots of each set were placed on an assigned bench in a glasshouse and maintained at $28 \pm 2^{\circ} \mathrm{C}$ and $65-70 \%$ relative humidity for 2 weeks before planting. Barley grains (Hordeum vulgare L.) Madini cultivar were sterilized in $2 \%$ sodium hypochlorite solution for $1 \mathrm{~min}$, washed thoroughly in a series of sterile water, and transferred into a sterilized plastic tray $(25 \times 40 \mathrm{~cm})$ 
containing a sheet of Whatman No. 1 chromatographic paper, then watered with adequate amount of sterile water and maintained in the dark at $28 \pm 2^{\circ} \mathrm{C}$ for $24 \mathrm{~h}$ to verify the viability of grains to be used. Five grains were sown, at equal distances, in each pot. The pots were maintained at $28 \pm 2^{\circ} \mathrm{C}$ and 65 $70 \%$ relative humidity; irrigation was carried out immediately after sowing, and every 3 days with equal amounts of sterile water. The data were collected after 15,30 and 45 days of cultivation; involving germination rate, viability of raised seedlings, root length, shoot length, dry weight and pigment content of healthy/survived plants (April and Sisnas, 1990; Gunther et al.,1996; Railley et al., 1996).

\section{Estimation of photosynthetic pigments contents}

The chlorophyll was extracted from known weights of fresh leaves using dimethyl formamide according to the methods described by Lichtenthaler (1987). The absorbance of the extract was measured at 664.5 $\mathrm{nm}$ for chlorophyll a; at $647 \mathrm{~nm}$ for chlorophyll b and at $452.5 \mathrm{~nm}$ for Carotenoids using a spectrophotometer (Spectronic DU 640). The concentrations of chlorophylls and caroteinoids were calculated according the formula given by Wellburn and Lichtenthaler (1984), as follows:

Chlorophyll $\mathrm{a}=12.7 \mathrm{E} 664.5-2.8 \mathrm{E} 647 \mu \mathrm{g} / \mathrm{ml}$,

Chlorophyll $b=20.13 \mathrm{E} 647-4.62 \mathrm{E} 664.5 \mu \mathrm{g} / \mathrm{ml}$,

Carotenoids $=4.2 \mathrm{E} 452.5-(0.0264 \mathrm{Chla}+0.426 \mathrm{chl} \mathrm{b}) \mu \mathrm{g} / \mathrm{ml}$.

Then, each of the three fractions was calculated on fresh weight basis (as $\mathrm{mg} \mathrm{g}^{-1}$ fresh wt.).

Statistical analysis

Data were analyzed following the statistical analysis system (SAS Institute, 1988). All multiple comparisons were first subjected to analysis of variance (ANOVA). Comparisons among means were made using the least significant difference (LSD) at $P \leq 0.05$ (Snedecor and Cochrane, 1989).

\section{RESULTS AND DISCUSSION}

The results depicted in Table 1 show that soil pollution with either benzene or toluene adversely affected germination of barley grains, and that benzene elicited stronger phytotoxicity than toluene; the percentage germination was $24-28 \%$, and $32-36 \%$, respectively. Moreover, $16 \%$ (in case of benzene- contaminated soil) and $12 \%$ (in toluene-contaminated soil) of the raised seedling died post emergence, and only $12 \%$ and $24 \%$ of plants remained alive up to the $45^{\text {th }}$ day of planting. This is in agreement with the results of Hou et al. (1999) who reported that the presence of volatile petroleum hydrocarbons in soils at relatively low concentration (4000-8000 $\mathrm{mg} / \mathrm{kg}$ dry soil) could severely hinder seed germination and result in poor plant establishment. The impact of soil pollution with petroleum hydrocarbons on seed germination and emergence of seedlings has been attributed to their phytotoxicity and/or physical impeding of water and oxygen transfer between the seed and surrounding soil environment, thus hindering the germination response (Adam and Duncan, 2002). 
Al-Tuwaijri, Majdah M. Y.

t1 
The results herein reported (Table 1) revealed that bacterial treatment of soil contaminated with benzene or toluene (using B. subtilis Bs2 or B. mycoides $\mathrm{Bm7}$ ) resulted in elimination of the deteriorative effect of these petroleum products, as evidenced by the pronounced increase in percentage germination and viability of seedlings.

Table 1 further show that $B$. subtilis seemed to have higher bioremediation potential than $B$. mycoides; the percentages germination in benzene- and toluene-contaminated soils were 76 and $80 \%$ following treatment with $B$. subtilis $\mathrm{Bs} 2$, whereas in case of $B$. mycoides $\mathrm{Bm} 7$, the corresponding percentages of germination were 52 and $60 \%$,respectively, throughout the experimental period. It may be interest to recall here that in a previous in vitro study $B$. subtilis Bs2 was found to exhibit higher hydrocarbon-degradation potential than $B$. mycoides $\mathrm{Bm} 7$ though both strains proved to be capable of utilizing benzene and toluene as sole source of carbon and energy (Al-Tuwaijri, 2009). The influential role of microorganisms in bioremediation of petroleum-polluted soil has been authenticated by many investigators (Aronstein et al., 1991; Hashem and Al-Obaid, 1996; Alexander, 1999). Hanson et al. (1997) have shown that the treatment of petroleumpolluted soil with Acinetobacter sp. A3 permitted better germination and growth of mungbean (Vigna radiate L.). These authors deduced that this bacterium was capable of reducing crude oil phytotoxicity through biodegradation.

The results presented in Figure 1 demonstrate that the root length of barley plants survived in soil amended with benzene or toluene decreased by about $92 \%$ of the control value throughout the various intervals. This is in conformity with the results of Petukhov et al. (2000) who reported that petroleum hydrocarbon pollution elicits phytotoxic effect on some plants like Avena sativa L., Secale cereale L. and Hordeum vulgare L., as evidenced by inhibition of seed germination, reduction in the total biomass and the length of the roots. The results herein reported (Fig. 1) further demonstrate that soil treatment with $B$. subtilis eliminated considerably the phytotoxic effects of both benzene and toluene on root length of barley; wherein the root length reached 75 and $85 \%$ of the control value, respectively, after 45 days. Soil inoculation with B. mycoides $\mathrm{Bm} 7$ elicited, however, lesser bioremediation efficiency than $B$. subtilis.

The results in Figure 2 show that shoot length of barley plants survived in benzene- or toluene-polluted soil was greatly reduced compared to control. Treatment with either bacterial strains resulted in well marked increments in plant height, thus the shoot length reached $69-75 \%$ of the control value following treatment with $B$. subtilis, whereas treatment with $B$. mycoides enhanced shoot length of plants grown in toluene-polluted soil but was ineffective in case of plants grown under the impact of benzene.

Prolongation of growth period had insignificant effect on plants grown under the impact of hydrocarbon pollution, whereas the shoot lengths of plants grown in unpolluted soil (control) or in polluted soil treated with bacteria exhibited progressive increase $(P<0.05)$ by increasing the plant age up to the $45^{\text {th }}$ day. 
The remarkable improvement in plant growth as indicated by the progressive increase in root length and plant height in response to bacterial treatments may be attributed to the biodegradation of petroleum hydrocarbons by the employed bacterial strains to non toxic intermediates (Atlas, 1995; Banke et al., 2000).

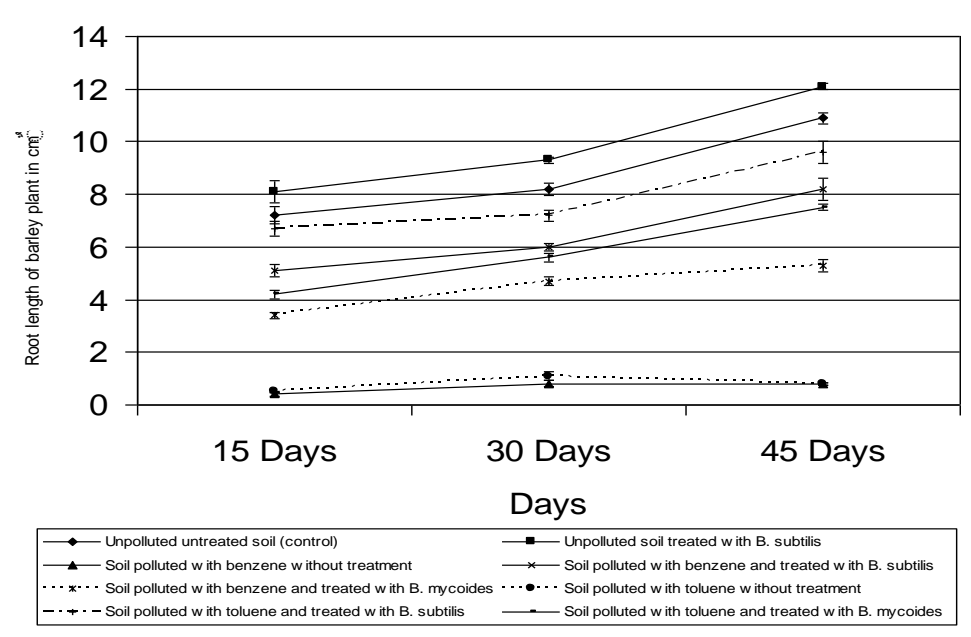

Fig. (1): Root length of barley plants grown under the impact of benzene or toluene pollution as influenced by bacterial treatment.

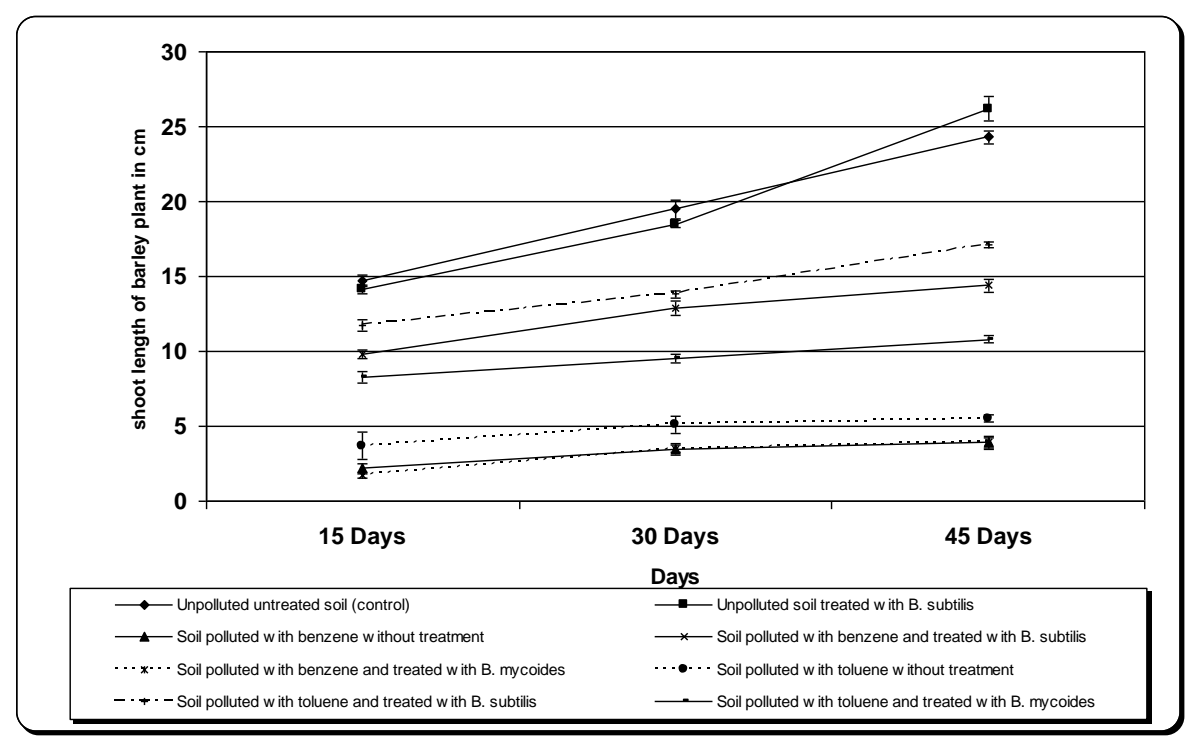

Fig. (2): Shoot length of barley plants grown under the impact of benzene or toluene pollution as influenced by bacterial treatment. 
The dry weight of barley plants exhibited similar response to soil pollution by benzene or toluene, as well as to the bacterial treatments (Fig.3). Thus, the dry weight of plants survived in polluted soil was greatly reduced; being about $13 \%$ of the control value in soil polluted with benzene and $15 \%$ in toluene-polluted soil, whereas the dry weight of plants grown in polluted soil treated with $B$. subtilis reached $40 \%$ (in case of benzene) and $47 \%$ (in case of toluene). However, soil treatment with $B$. mycoides resulted in lesser biomass gain, being $21 \%$ of the control value after 15 days and reached $35 \%$ on the $45^{\text {th }}$ day.

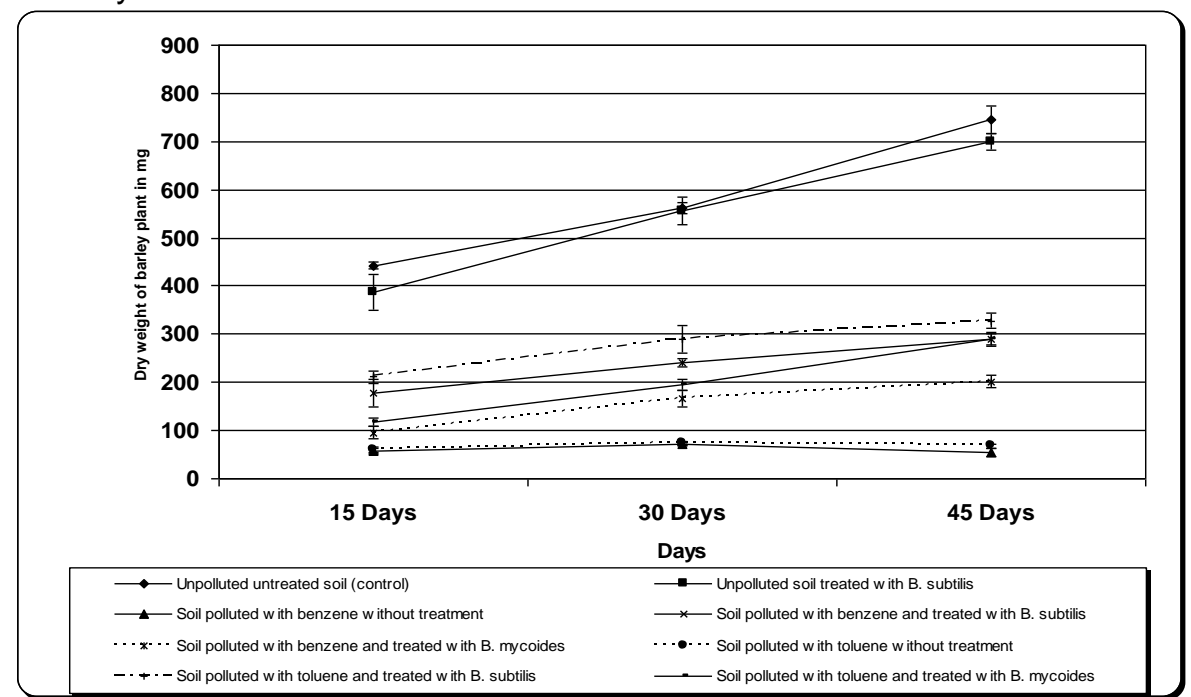

Fig. (3): Dry weight of barley plants grown under the impact of benzene or toluene pollution as influenced by bacterial treatment.

The response of photosynthetic pigments contents of barley leaves to the impact of benzene and toluene in untreated or in bacterial-treated soil is presented in Figure 4. It is apparent that both hydrocarbons caused highly significant decreases in chlorophylls and carotenoids contents of leaves as compared to control during the first 15 days. Thereafter, chlorophyll a content continued to decrease up to the 45 days, whereas chlorophyll $\mathrm{b}$ and carotenoid contents were not significantly affected by prolongation of growth period. It is possible that the effect of petroleum hydrocarbons on chlorophylls and carotenoids is an attenuation of the biosynthetic rate rather than a breakdown of pigments already formed. In case of plants grown in polluted soil treated with either $B$. subtilis or $B$. mycoides, chlorophyll a contents and consequently the total pigments were increased considerably by time.

It has been reported that petroleum hydrocarbon pollution may affect plants by retarding seed germination and reducing plant height, biomass and photosynthetic rate or resulting in complete mortality (Mendelssohn et al., 1990; Lin and Mendelssohn, 1996; Pezeshki et al., 2000). In the present study most reductions in growth and viability of barley plants due to petroleum hydrocarbons occurred within the early stages of growth particularly in root length. 
Al-Tuwaijri, Majdah M. Y.
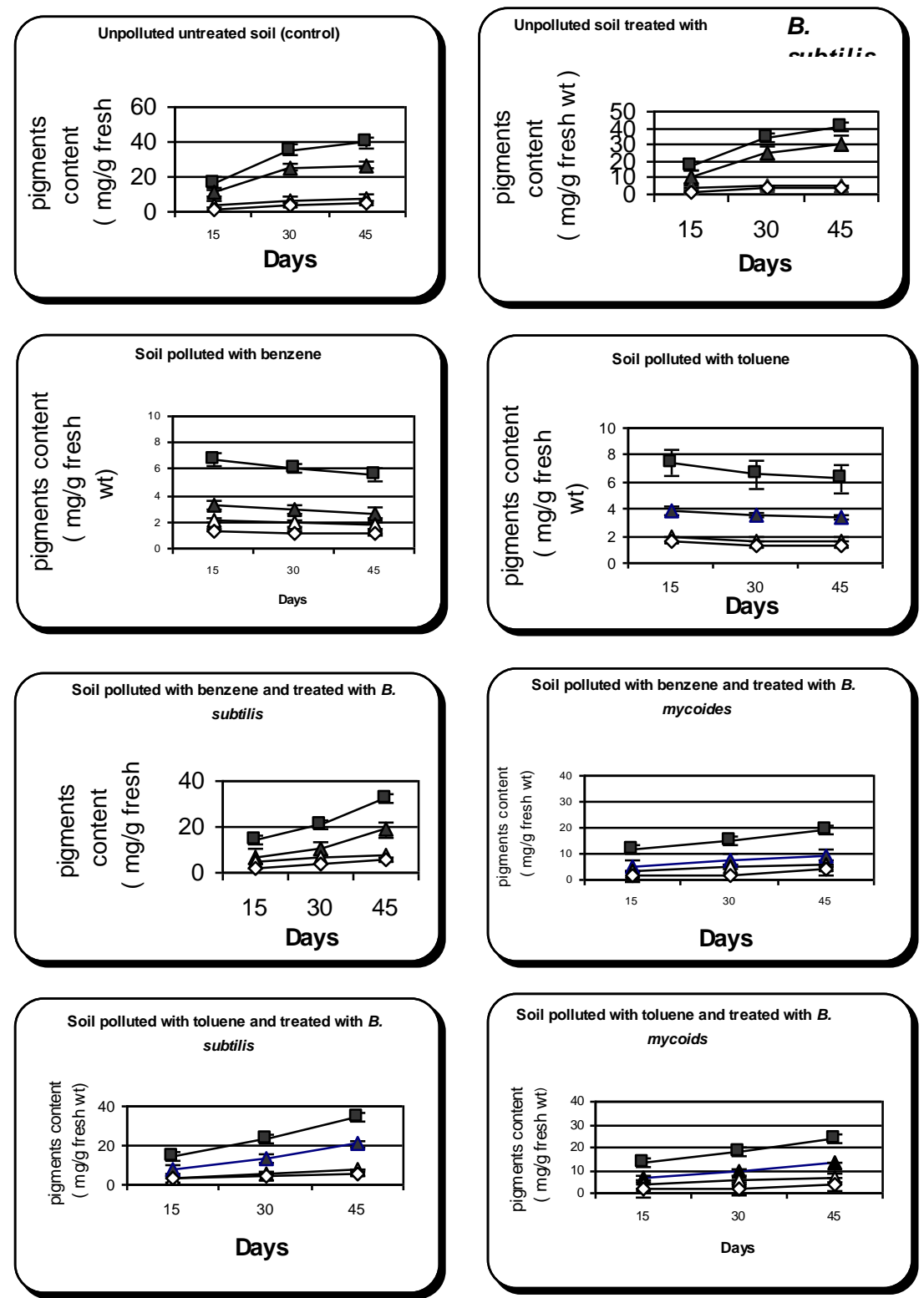

Fig. 4. Pigments contents of leaves of barley plants grown in unpolluted soil (control) and in hydrocarbon-polluted soil untreated or treated with the experimental bacterial strains.

n------n = total pigments ; $L S D=0.266,0.163,0.517$, at $15,30 \& 45$ days, respectively

$\Delta$---- $\Delta=$ chlorophyll a ; LSD $=0.253,0.155,0.444$, at $15,30 \& 45$ days, respectively.

$\Delta$------- $\Delta=$ chlorophyll b ; LSD $=0.230,0.140,0.506$ at $15,30 \& 45$ days, respectively. $\diamond-----\otimes=$ caroteinoids ; LSD $=0.447,0.275,0.894$ at $15,30 \& 45$ days, respectively. 
This might point to the higher sensitivity of roots than shoots, and consequently some $(8-12 \%)$ of the emerged seedlings (about $40-50 \%$ of the control) died within the first 15 days. This might imply that these petroleum substances affect plant growth mainly through their adverse effect on water uptake and transport of nutrients from root to shoot.

Achuba (2006) reported that the chlorophyll contents of the leaves of 12-day-old seedlings of cowpea (Vigna unguiculata) were decreased by the various sublethal concentrations of crude oil. Petroleum pollution is a serious obstacle to photosynthesis. Duke et al. (2000) and Duke and Walkinson (2002) have demonstrated that oil contamination of sediment resulted in albinos seedlings of Avicennia marina; some plants die and others survive and have possible sub-lethal responses.

The present investigation clearly established the fact that Bacillus subtilis Bs2, and to lesser extent, B. mycoides $\mathrm{Bm} 7$ play an influential role in bioremediation of petroleum-polluted soil irrespective of the observed reduction in growth vigor of barley plants as compared to the plants grown in unpolluted soil (control). In this connection, it is worth to mention that Mergesin and Schinner (1997) stated that the hydrocarbon content of soil cannot be diminished to zero and always remain between $10-30 \%$. This may lend a plausible explanation to our findings. Nevertheless, the results herein reported may emphasize the influential role of the experimental bacterial strains (Bacillus subtilis B52 and B. mycoides Bm7) in bioremediation of hydrocarbon- polluted soil in Saudi Arabia.

\section{REFERENCES}

Abu-Zinada, A.H. and Sabek, A.M.(1980). Hydrocarbon-utilizing microorganisms from Eastern and Central Provinces of Saudi Arabia. Proc. Saudi Biol. Sci., 4: $153-162$.

Achuba, F.I. (2006). The effect of sublethal concentrations of crude oil on the growth and metabolism of cowpea (Vigna unguiculata) seedlings. The Environmentalist, Springer Netherlands, 26 (1): 217-220.

Adam, G. and Duncan, H. (2002). Influence of diesel fuel on seed germination. Environ. Pollut., 120(2): 363-370.

Alexander, M. (1999). Biodegradation and Bioremediation. $2^{\text {nd }}$ ed., New York ,San Diego, CA., 453p. New York Academic Press.

Al-Tuwaijri, Majdah M.Y. (2009). Isolation and characterization of bacteria capable of degrading benzene and toluene from petroleum contaminated soil in Saudi Arabia. Egypt. J. Biotech., 32: 54-66.

April, W. and Sisnas, R.C. (1990). Rhizosphere microbial population in contaminated soil. Chemosphere, 20: 253-256.

Aronstein, B.N.; Calvillo, Y.M. and Alexander, M. (1991). Bioremediation. Environ. Sci. Biotech., 25: 1728-1731.

Atlas, R.M. (1995). Petroleum biodegradation and oil spill bioremediation. Mar. Pollut. Bull., 31: 178-182.

Atlas, R.M. (1981). Microbial degradation of petroleum hydrocarbons: An environmental perspective. Microbiol. Rev., 45: 180-209. 
Banke, M.K.; Govindaraju, R.S.; Schwab, A.P. and Kulakow, P. (2000). Part 1: Field demonstration. In S. Fiorenza, C.L. Oubre, and C.H. Ward (eds), Phytoremediation of Hydrocarbon-Contaminated Soil. Baton Rouge, Lewis Publishers, pp. 3-88.

Chaineau, C.H.; Morel, J.; Dupont, J. and Oudot, J. (1999). Comparison of the fuel oil biodegradation potential of hydrocarbon assimilating microorganisms isolated from temperate agriculture soil. Sci. Total Environ., 227(2-3): 237-247.

Dorota, W.; Suszek, A.; Borkowski, A. and Bielecka, A. (2009). Application of aerobic microorganisms in bioremediation in situ of soil contaminated by petroleum products. Bioresource Technol. 100(13): 3221-3227.

Duke, N.C. and Watkinson, A.J. (2002). Chlorophyll-deficient propagules of Avicennia marina and apparent longer term deterioration of mangrove trees in oil-polluted sediments. Mar. Pollut. Bull., 44: 1249-1276.

Duke, N.C.; Burns, K.A.; Swannell, R.P.J.; Dalhaus, O. and Rupp, R.J. (2000). Dispersant use and a bioremediation strategy as alternate means of reducing the impact of large oil spills on mangroves: The Gladstone Field Trials. Mar. Pollut. Bull., 41: 403-412.

El-Baz, F. (1992). Preliminary observations of environmental damage due to Gulf War. Natural Resources Forum, 165: 71-75.

Gunther, T.; Dornberger, U. and Fritsche, W. (1996). Effects of ruegrass on biodegradation of hydrocarbons. Chemosphere, 33: 203-215.

Hanson, K.G.; Nigam, A.; Kapadia, M. and Desai, A.J. (1997). Bioremediation of crude oil contamination with Acinetobacter sp. A3. Current Microbiol., 35(3): 191-193.

Hashem, A.R. (1995). Crude oil utilization by fungi isolated from the soil of industrial Yanbu City, Saudi Arabia. Geobios., 22: 121-124.

Hashem, A.R. (1996). Influence of crude oil contamination on the chemical and microbiological aspects of Saudi Arabian Soils. J. King Saud Univ. Sci., 8(1): 11-18.

Hashem, A.R. (2004). Biological treatment of petroleum contamination in Saudi Arabia. J. Natural Appl. Sci., 8(2): 321-327.

Hashem, A.R. and Al-Obaid, A.M. (1996). Degradation of Gasoline by Aspergillus flavus isolated from Saudi Arabian Soil. Geobios., 23(4): 185-188.

Hou, F.S.L.; Leung, D.W.M.; Milke, M.W. and MacPherson, D.J. (1999). Raygrass, seed germination for diesel contaminated soils by peg treatment technology. Environ. Technol., 20 (4): 413-418.

ljah, U.J.J. and Ukpe, L.I. (1992). Biodegradation of crude oil by Bacillus strains $28 \mathrm{~A}$ and $61 \mathrm{~B}$ isolated from oil spilled soil. Waste Manage., 12: 55-60.

Inoue, A. and Horikoshi, K. (1989). A Pseudomonas thrives in high concentration of toluene. Lett. Nature, 338: 264-266.

Kim, J.K.; Kam,S.K. and Lee,M.G. (2008). Characteristics of benzene, toluene and xylene gas removal by a biofilter using scoria. Inter. J. Environ. Pollut., 39: 264-278. 
Lee, S.K. and Lee, S.B. (2001). Isolation and characterization of thermotolerant bacterium Ralstonia sp. Strain PHS1 that degrades benzene, toluene, ethyl benzene and o-xylene. Appl. Microbiol., 56: 270-275.

Lehmann, V. (1998). Bioremediation: A solution for polluted soils in the South?. Biotech. Develop. Monitor, 34: 12-17.

Lichtenthaler, H.K. (1987). Chlorophylls and carotenoids: Pigments of photosynthetic biomembranes. Methods Enzymol. 148: 350-382.

Lin, Q. and Mendelssohn, I.A. (1996). A comparative investigation of the effects of Louisiana crude oil on the vegetation of fresh, brackish and salt marshes. Mar. Pollut. Bull, 32 (2): 202-209.

Mendelssohn, I.A.; Hester, M.W.; Sasser, C. and Fischel, M. (1990). The effect of a Louisiana crude oil discharge from a pipeline break on a vegetation of a southeast Louisiana brackish marsh. Oil Chem. Pollut., 7: 1-15.

Mergesin, R. and Schinner, F. (1997). Bioremediation of diesel oilcontaminated alpine soil at low temperature. Appl. Microbiol. Biotech., 47: 462-468.

Petukhov, V.N.; Fomchenkov, V.M.; Chugunov, V.A. and Kholodenko, V.P. (2000). Plant biotests of soil and water, polluted with oil and oil products. Appl. Biochem. Microbiol., 36(6): 564-567.

Pezeshki, S.R.; Hester, M.W.; Lin, Q. and Nyman, J.A. (2000). The effects of oil spill and clean-up on dominant US Gulf coast marsh macrophytes: a review. Environ. Pollut., 108: 129-139.

Raymond, R.L.; Jamison, V.W. and Hudson, J.O. (1967). Microbial hydrocarbon co-oxidation. 1. Oxidation of mono- and dicyclic hydrocarbons by soil isolates of the genus Nocardia. Appl. Microbiol., 15: 857-865.

Reardon, K.F.; Mosteller, D.C. and Rogers, J.D. (2000). Biodegradation kinetics of benzene, toluene and phenol as single and mixed substrates for Pseudomonas putida F1. Biotech. Bioengin, 69(4): 385400.

Reilley, K.A.; Banks, M.K. and Schwab, A.P. (1996). Dissipation of polycyclic aromatic hydrocarbons in the rhizosphere. J. Environ. Qual., 25: 212 229.

Rowland, M. and Atlas (1995). Bioremediation of petroleum pollutants. Inter. Bioremed. Biodegrad., 35: 317-327.

Rosenberg, E. (2006). Hydrocarbon-oxidizing bacteria. In: M. Dworkin; S. Falkowi, E. Rosenberg; K.H. Schleifer and E. Stackebrandt (eds.). The Prokaryotes, a Handbook of the Biology of Bacteria, $3^{\text {rd }}$ edn., Vol. 2, Springer, Berlin, pp. 564-577.

Saadoun, I. and Alawawdeh, M. (2008). Growth of Streptomyces spp. from hydrocarbon-polluted soil on diesel and their analysis for the presence of alkane hydroxylase gene (alk B) by PCR. World J. Microbiol. Biotech., 24: 2191-2198.

Sallal, A.J. (1995). Effect of crude oil and benzene on growth, photosynthesis and glyollate dehydrogenase of Anacystis nidulans. Arab Gulf Sci., 13(2): 357-367. 
SAS Institute (1988). SAS System for Elementary Statistical Analysis, ed. Schlothauer and Littell, ISBN 1-55544-076-2.

Snedecor, G.W. and Cochrane, W.G. (1989). Statistical Methods. lowa State Univ. Press, lowa, USA.

Utkin, I.B.; Yakimor, M.M.; Matveera, L.N.; Kozlyok, E.L.; Rogozhin, I.S. and Bezborodov, A.M. (1992). Degradation of benzene, toluene and xylene by a Pseudomonas sp. 13 culture. Appl. Biochem. Microbiol., 28: 275280.

Venosa, A.D.; Suidan, M.T.; Wrenn, B.A.; Skrohmeier, K.L.; Haines, J.R.; Eberhart, B.L.; King, D. and Holder, E. (1996). Bioremediation of an experimental soil spill on the shoreline of Delaware Bay. Environ. Sci. Technol., 30: 1764-1775.

Wellburn, A.R. and Lichtenthaler, H. (1984). Formula and program to determine total carotenoids and chlorophylls $a$ and $b$ leaf extracts in different solvents. In: Advances in biosynthesis research (ed. C. Sypesma), Vol. II: 9-12.

Yakubu, M.B. (2007). Biological approach to oil spills remediation in the soil. Afr. J. Biotech., 6(24): 2735-2739.

Yudono, B.; Said, M.; Hakstage, P. and Suryadi, F.X. (2009). Kinetics of indigenous isolated bacteria Bacillus mycoides used for Ex-Situ bioremediation of petroleum contaminated soil in PT Pertamina Sungai Lilin South Sumatra. J. Sust. Develop. , 2 (3): 64-71.

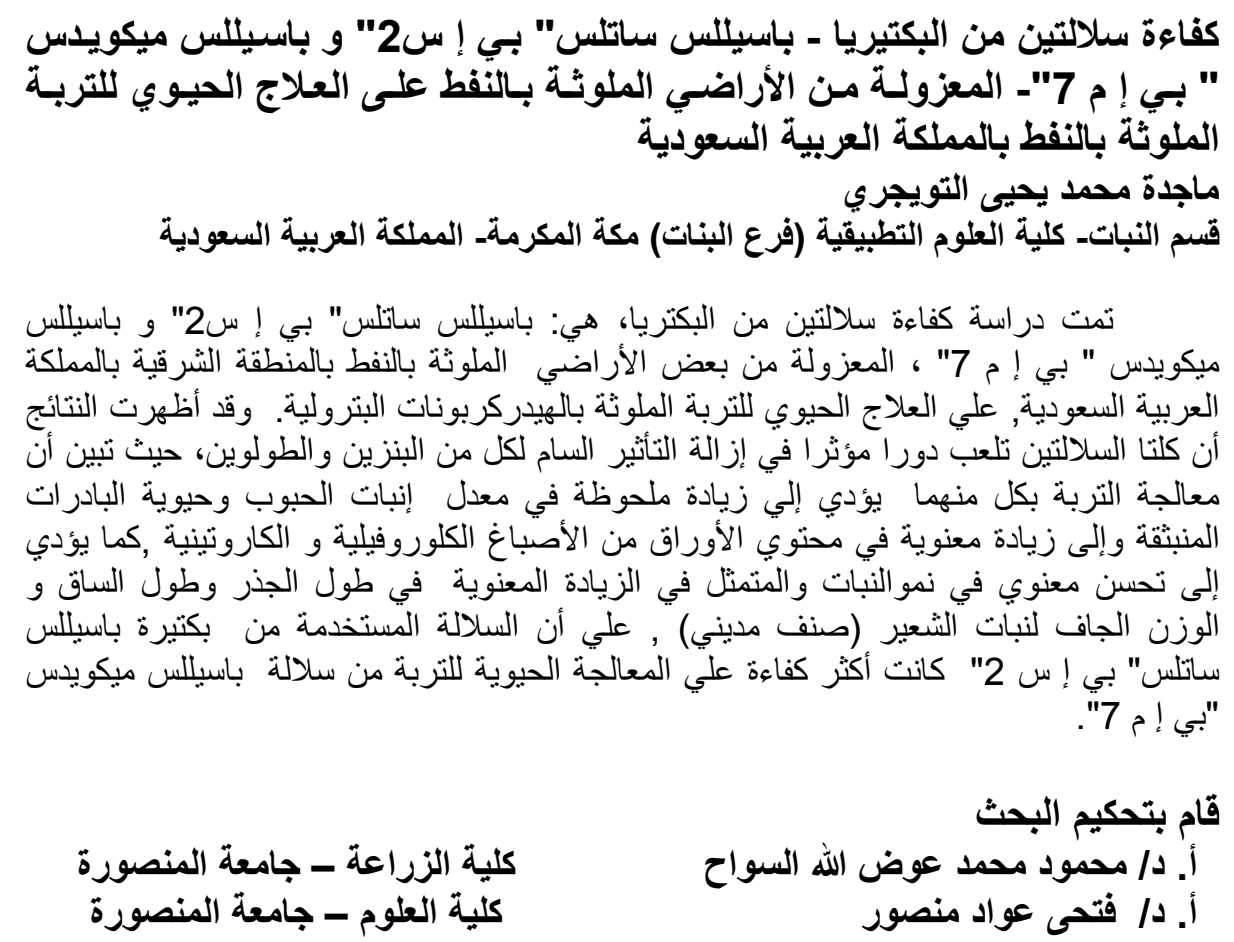


J. of Agricultural Chemistry and Biotechnology, Vol. 1 (1):11 - 22, 2010 
Al-Tuwaijri, Majdah M. Y. 
Table 1: Response of grain germination and viability of emerged seedlings of "Madini " barley cultivar to soil pollution with petroleum hydrocarbons and treatment with B. subtilis Bs 2 and B. mycoides Bm7

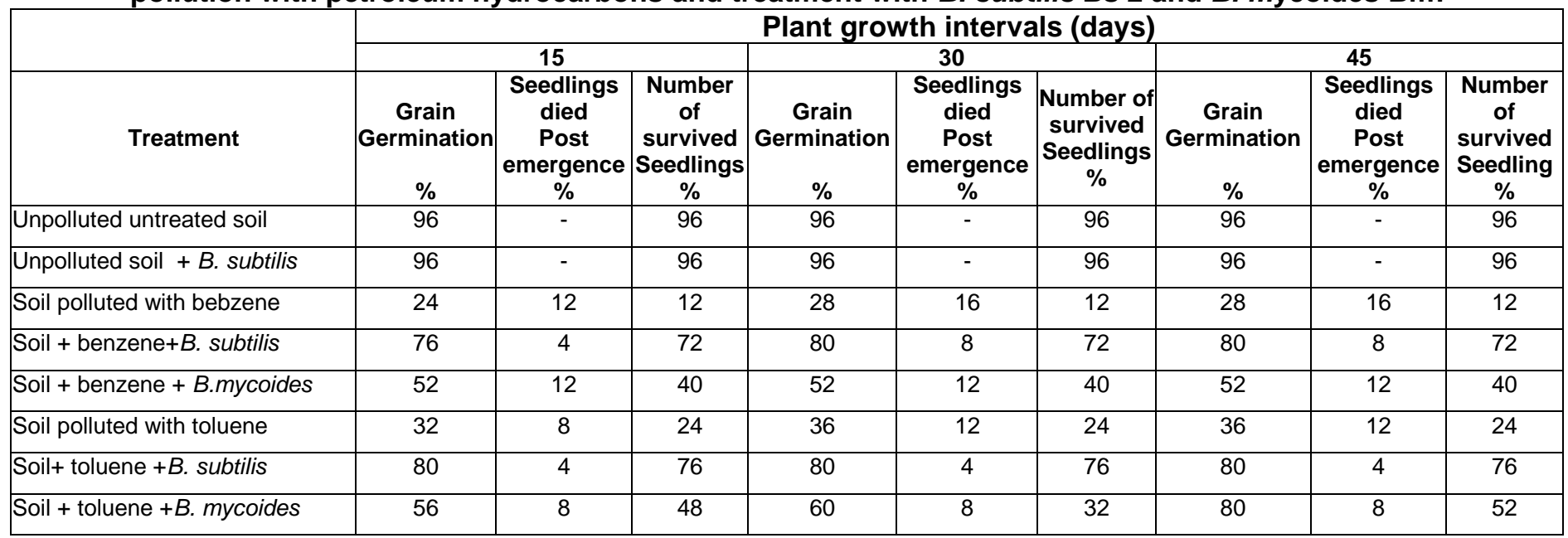


Al-Tuwaijri, Majdah M. Y. 